\title{
音声と画像の統合によるドライバの発話区間検出
}

\section{Voice Activity Detection for Driver Using Audio-Visual Integration}

\author{
正会員 二 宮 芳 樹†, \\ 宮島 千代美㹨,
}

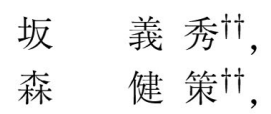

前 野 俊 希胡,

北坂孝幸故,
根木大 輔计, 末永康仁计

Yoshiki Ninomiya $^{\dagger}$, Yoshihide Ban ${ }^{\dagger \dagger}$, Toshiki Maeno ${ }^{\dagger \dagger}$, Daisuke Negi ${ }^{\dagger \dagger}$, Chiyomi Miyajima $^{\dagger \dagger}$, Kensaku Mori ${ }^{\dagger \dagger}$, Takayuki Kitasaka ${ }^{\dagger \dagger}$ and Yasuhito Suenaga ${ }^{\dagger \dagger}$

\begin{abstract}
Voice activity detection is an important part of the development of speech functions for on-board car navigation and assistance systems. It is difficult to detect voice activity using only sound information in a vehicle environment that has a wide variety of sounds and noises. We propose an suitable image feature and integration method that can be used to develop a robust bimodal voice activity detection(VAD) systems using a driver's voice and facial images. We select the normal correlation value between sequential mouth images and the number of low-intensity pixels in mouth image, which we then used as the feature for VAD. We propose a system in which the discrimination function consist of the sum of weighted singles feature discrimination functions and combinations of logical addition and multiplication of singles feature discrimination functions. The experimental results show that the proposed sound and image features can be useful and that the proposed integration method has a $97 \%$ hit rate, which is 9 points better than the previous integration method at the point that false alarm rate is about $12 \%$.
\end{abstract}

キーワード : 発話区間検出, ドライバ, 特徵統合, バイモーダルインタフェース, 山唇画像, 音声認識

\section{1. ま え がき}

カーナビのユーザビリティ向上のために音声インタフェー スが期待されている。課題の一つは主として車室内の雑音 に起因した音声認識の性能不足である. 対策として音声信 号からの雑音除去 ${ }^{1)}$, 雑音への音響モデル 適応 ${ }^{2)}$, 狭指向 性マイクの利用 ${ }^{3)}$ などがあるが充分でない. そこで本研究 では, 音声に加えて画像情報を用いるいわゆるバイモーダ ルの手法で問題解決を試みる。画像情報を得るには顔を撮 像する車内カメラが必要になる。車内カメラは, 脇見・居 眠り検知，セキュリティなどの用途での実用化が始まり ${ }^{4)}$, 今後の普及も予測されている.

音声認識処理は, 対象となる発話部分を切り出す発話区

2003 年 3 月, 電子情報通信学会 研究会で発表

2007 年 9 月 18 日受付, 2007 年 11 月 20 日再受付, 2007 年 12 月 7 日 採録

††名古屋大学 大学院 情報科学研究科

( $\bar{T} 464-8603$ 愛知県名古屋市千種区不老町, TEL 052-789-5688)

$\dagger$ †株) 豊田中央研究所

( $\bar{T} 480-1192$ 愛知目愛知郡長久手町大宁長湫宁横道 41-1, TEL 0561-634300)

$\dagger \dagger$ Graduate School of Information Science, Nagoya University (Furo-cho, Chikusa-ku, Nagoya-shi, Aichi, 464-8603 Japan) $\dagger$ Toyota Central R \& D Lab., Inc.

(Aza Yokomiti 41-1, Ooaza Nagakute, Nagakute-cho, Aichi-gun, Aichi, 480-1192 Japan)
間検出 $\left(\mathrm{VAD}^{*}\right)$ と切り出した発話区間に対する狭義の音声 認識処理から成る.VADの結果に音声認識性能は大きく 依存するため, VAD は音声認識の重要な要素技術である. 本研究は, 音声と画像によるバイモーダルの VAD を対象 とし, 車室内の雑音時に有効な画像の発話特徴と咅声およ び画像の発話特徴の統合法の提案を目的とする.

画像発話特徴は, ドライバの顔画像から口唇周辺の画像 (以後，それぞれドライバ画像，口唇画像と記す）を切り 出し，そこから特徴を算出するのが一般的である。従束用 いられた局所的特徴としては口唇の形状 ${ }^{5) \sim 7), ~ オ フ ゚ テ ィ カ ~}$ ルフロー879) がある。しかし, 車内画像は夜間照明の必要 性から近赤外画像であり，口唇の形状は不吸暸になる。ま た，多様なドライバの体格・着座位置に対応した広画角力 メラを用いるため, オプティカルフローは安定した検出が 難しい.

また, 従来用いられた全体的特徵としてロ唇丒像のフレー ム間輝度差分がある ${ }^{10) 11)}$. しかし, 車内画像では顔の動き や外乱光による照明変動が大きく, 輝度差分はそれらに頑 健でない．筆者らはこれらの課題に対応できる特徴として， 正規化輝度差分を提案した. 動きに対して追跡処理, 照明 変動に対して正規化相関で対策したものである。また，筆

\footnotetext{
*Voice Activity Detection
} 
者らは発話による口腔開度を示す特徴として, 低輝度画素 数抢よびそのフレーム間差分を提案した。これは発話時に 発生する口腔内の暗い領域の大きさおよびその変化を表す もので, 顔の動きや照明变動の影響を受けにくい特性があ る.これらの特徵に対して比較評価し, 効果の確認を行っ たが, 評価データが少数の空開け時の実車走行の場合に限 定されていた ${ }^{12)}$.

バイモーダルのVAD のための音声と画像の統合法は, そ れぞれの特徵量に基づく線形判別関数の論理和や論理積を 用いる例 ${ }^{13)}$ が多い。しかし，車内環境では充分な評価がな されていない，筆者らは音声の対数パワーと画像の低輝度 画素数フレーム差分のそれぞれの線形判別関数の論理積で 発話区間を検出した。評価の結果, 音声雑音に対するロバ スト性向上などのバイモーダルの利点を確認できた ${ }^{12)}$. し かし, この方法では口の動きが小さい場合の未検出が課題 となった。 また, 判別関数の閾値をデータごとに人手で調 整していたので, 閾值の設定法も未解決であった。そこで 筆者らは, 口の小さな動きに対応するため, 音声発話特徴 の閾値に画像発話特徴でオフセットを加える統合法と, 閾 值を自動的に設定するための浮動閾値設定法による対策を 実施した ${ }^{14)}$ 。これにより未検出を低減できたが, 音声特徵 による判別を主体としたため, 音声雑音による誤検出が増 加した。 また，閾值制御のパラメー夕調整の難しさが指摘 された。

本論文は以上の残存課題解決を目的とし, 筆者らが提案 した画像発話特徵を用いて, パラメー夕調整を自動化し, 新 たな音声と画像の統合法を提案し, 実際の車内環境の雑音 に対応できる検出精度が高いバイモーダルの発話区.間検出 を実現する。またそのために従来の限定条件でなく多様な 音声雑音を含むデー夕を用い, ROC 曲線*による定量的な 評価を行う.

以下，第 2 節ではこれまでに提案した音声および画像の 発話特徴を示し, 両者の特徵統合法を提案する. 第 3 節で は実走行車内環境下で提案方法を評価し, その考察を示す。 最後に第 4 節でまとめと今後の課題について述べる.

\section{2. 音声と画像の統合による発話区間検出}

\section{1 音声発話特徴}

車内音声の例を図 1 に示す.サンバイザー付近の音声認 識用のハンズフリーマイクと参照用の接話マイクで収集し た音声データ例**である. 背景雑音としてエアコンの吹き 出し音が入った音声の一例であるが, ハンズフリーマイク の音声に大きな雑音 (約-10dB) の重畳が確認できる，音 声の発話特徵として, 一般的な発話時の音の増大に着目し た音声対数パワー値と発話音の特性に着目した零交差数お よびそれぞれのフレーム間差分を用いた。対数パワー值は ノイズの影響を受けやすいので, 前処理として音声強調処

\footnotetext{
* Receiver Operating Characteristic Curve

** 7.7 秒間の連続数字” $14700 ":$ イチコンナナゼロゼロの発話
}
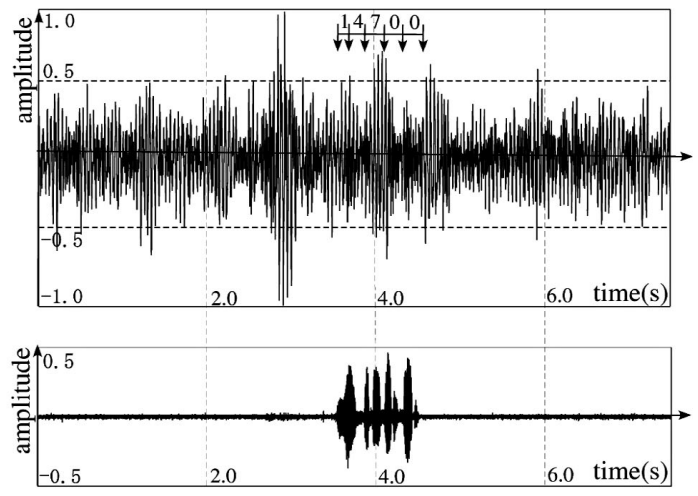

図 1 音声データ例（上:ハンズフリーマイク,下：接話マイク Examples of speech signals. (Top: Handsfree mic,Bottom: Headset mic)

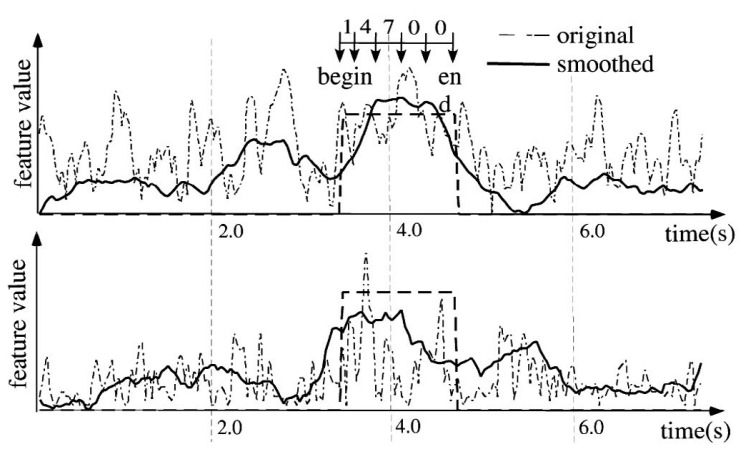

図 2 発話特徵例 (上 : 対数パワー,下:零交差数) Examples of feature values for VAD. (Top: Log power of audio signals) (Bottom: Number of zero crossing)

理 15 を用いた。

音声特徵は画像の撮像周期（1フレーム $=33 \mathrm{ms）ごと}$ に算出する。音声信号 $g(n)$ ( $n$ :サンプル位置), 音声強調処 理を施した音声信号 $g^{\prime}(n)$ に対して $t$ 番目の画像のフレー ムでの対数パワー值 $F_{a L P}(t)$ は式 $(1)$, 零交差数 $F_{a Z C}(t)$ は式 (2) で表される.

$$
\begin{aligned}
F_{a L P}(t) & =\log \sum_{n=n_{t}}^{n_{t}+N_{f r}} g^{\prime}(n)^{2} \\
F_{a Z C}(t) & =\sum_{n=n_{t}}^{n_{t}+N_{f r}} f_{z c}(g(n)) \\
f_{z c}(g(n)) & = \begin{cases}1 & (g(n) \cdot g(n-1)<0) \\
0 & (\text { 上記以外 })\end{cases}
\end{aligned}
$$

$n_{t}$ は $t$ 番目の两像フレームの開始時点の音声信号のサンプ ル位置, $N_{f r}$ は 1 フレーム分の音声サンプル数, $f_{z c}(g(n))$ は $n$ 番目のサンプルにおける零交差の有無を 1,0 で表した 関数である.

図 1 のハンズフリーマイクの音声データから算出した発 話特徵例を図 2 に示す.フレーム単位で算出した特徵値（図 2 の一点鎖線）は発話区間内でも变動し, 非発話区間でも パルス状の高い值となる。そこで, 0.8 秒の単純平均によ 


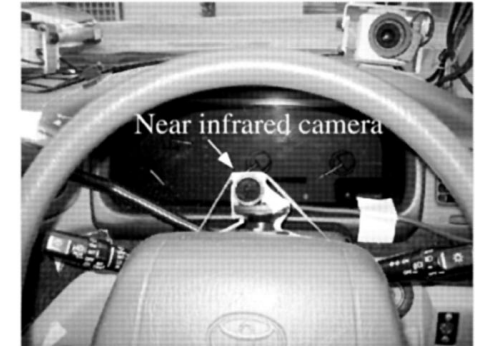

図 3 車載近赤外カメラ In-vehicle near infrared camera.

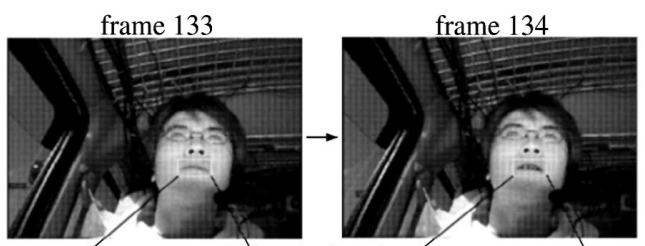

Driver's face image
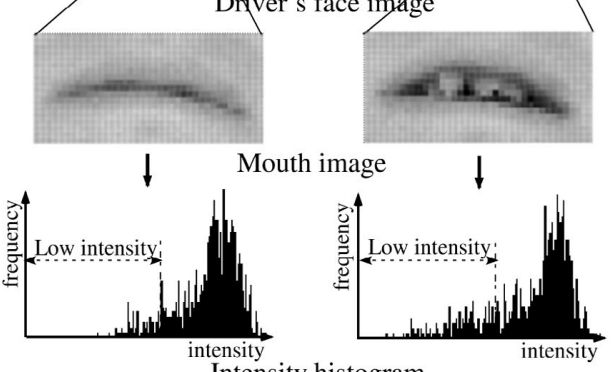

Intensity histogram

図 4 ドライバ西像, 口唇两像, 濃度ヒストグラムの例 Examples of driver's face, mouth images, and intensity histogram.

る平滑化処理を加えて, 特徵值が発話区間内で連続的に高 い值を持ち，非発話区間での雑音の影響を抑えるようにし た(図 2 の実線)。

\section{2 画像発話特徵}

ステアリングコラム搭載の近赤外カメラ (図 3) のドライ バ画像 $(352 \times 240$ 画素) と口付近の画像を切り出した口唇 画像 $(20 \times 10$ 画素) 㧍よびその濃度ヒストグラムを図 4 に 示す. 夜間, トンネル時の必要性から照明には近赤外 LED を用い，外乱光対策のためにカメラ側に可視光カットフィ ルタを装着している，口唇画像は，前節の音声データと同 一の連続数字発話時のものであり, 発話に伴うフレーム間 の画像変化が確認できる. 口唇画像の切り出しは, 可視光 画像で一般的な色や唇輪郭形状による唇の検出法の適用は 困難なため，筆者らが提案した濃淡劣化による目，鼻，口 のパーツ候補の検出とそれらの位置関係による顔位置およ び口唇位置検出法 ${ }^{16)}$ を用いた。

口唇画像から算出する画像発話特徵としては筆者らが従 来提案したものを中心に選択した。

発話に伴う口の動き（画像の変化）を表す特徵として正規 化差分を用いる。これは従来から用いられているフレーム 間輝度差分の顔の動きと照明変動への課題を，相関処理によ る時系列追跡と正規化相関の導入でそれぞれ解決したもの である. 正規化差分 $F_{v N D}(t)$ は $t$ 番目のフレームの口唇画
像 $i_{t}(r)\left(r=1,2, . ., N_{m i}\right.$, 総画素数 $\left.N_{m i}=10 \times 20=200\right)$ と 1 フレーム前の口唇画像 $i_{t-1}(r)$ との正規化相関による 位置照合を行い，算出された相関值を 1 から減ずることに よって算出する(式 (4)).

$$
\begin{gathered}
F_{v N D}(t)=1-\frac{\sum_{r=1}^{N_{m i}}\left(i_{t}(r)-\bar{i}_{t}\right)\left(i_{t-1}(r)-\bar{i}_{t-1}\right)}{\sqrt{\sum_{r=1}^{N_{m i}}\left(i_{t}(r)-\bar{i}_{t}\right)^{2}} \sqrt{\sum_{r=1}^{N_{m i}}\left(i_{t-1}(r)-\bar{i}_{t-1}\right)^{2}}} \\
\bar{i}_{t}: t \text { 番目のフレームの画像中の輝度 } i_{t} \text { の画素平均值 }
\end{gathered}
$$

図 4 の口唇画像の輝度ヒストグラムから, 図中の低輝度領 域 (Low Intensity)において，発話に伴う開口によって低 い値を持つ画素数が増加していることがわかる．口腔の開 度を表す低輝度画素数 $F_{v L N}(t)$ は $t$ 番目のフレームの口唇 画像 $i_{t}(r)$ の中の閾值 $\Theta_{v L N}$ 以下の值を持つ画素の数とし て算出される (式 $(5))$.

$$
\begin{aligned}
F_{v L N}(t) & =\sum_{r=1}^{N_{m i}} f_{L N}\left(i_{t}(r)\right) \\
f_{L N}\left(i_{t}(r)\right) & = \begin{cases}1 & \left(i_{t}(r)<\Theta_{v L N}\right) \\
0 & (\text { 上記以外 })\end{cases}
\end{aligned}
$$

閾值 $\Theta_{v L N}$ は，低輝度画素数が発話に伴う開口時に人きく， 非発話時に小さくなるように，評価サンプル以外のデー夕 を用いて，発話時と非発話時の低輝度画素数の差が最大值 となる値に調整した。また，低輝度画素数のフレーム間差 分により，口の動きを表す発話特徽が算出できる。低輝度 画素数は正規化差分と比べると，開口により口腔が見える 場合のみ值を持つが，口の動きへの感度は高い，両者は一 長一短を持つ特徵なので今回この二つを比較評価する。

画像に基づく発話特徽の実例として，フレーム間輝度差 分と正規化差分值を図 5 に示す。この例では顔の動きによ る照明変動があり，筆者らの検討 ${ }^{12)}$ で指摘したようにフ レーム間輝度差分はその影響を強く受け，正規化差分は影 響を受けにくいことが確認できる．図 6 は同じ例での低輝 度画素数掞よびそのフレーム間差分值を示すもので，これ らも照明変動の影響を受けにくいことがわかる.

\section{3 音声と画像統合による発話区間検出}

第 $2.1 ， 2.2$ 節でそれぞれ示した音声と画像に基づく発話 特徴の統合による発話区間検出手法を示す。これはセンサ統 合の問題であり，特徵ごとに判別関数を構成し，その結果を 統合する決定段階統合法と，複数特徵を一つの多次元特徵 として統合してから判別関数を構成する特徵段階統合法が ある。また，決定段階統合法には Bayes 推定，DempsterShafer 法, Fuzzy 推論，投票方式などのルールベース統合 などの方法がある ${ }^{17)}$.

筆者らは計算コストの小さいルールベース統合法，すな わち特徵ごとの線形判別関数の論理積・和，投票などで全 体の判別関数を構成する方法を採用してきた．最初に提案 したのは音声と画像のそれぞれ一つずつ, 計二つの特徴量 


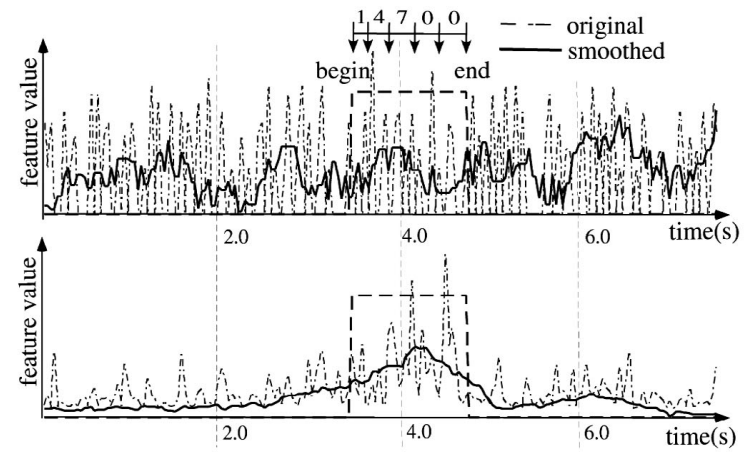

図 5 発話特徵例（上：フレーム間輝度差分,下:正規化差分） Examples of feature value for VAD.

(Top: Intensity difference between two adjacent frames) (Bottom: Normalized difference between two adjacent frames)

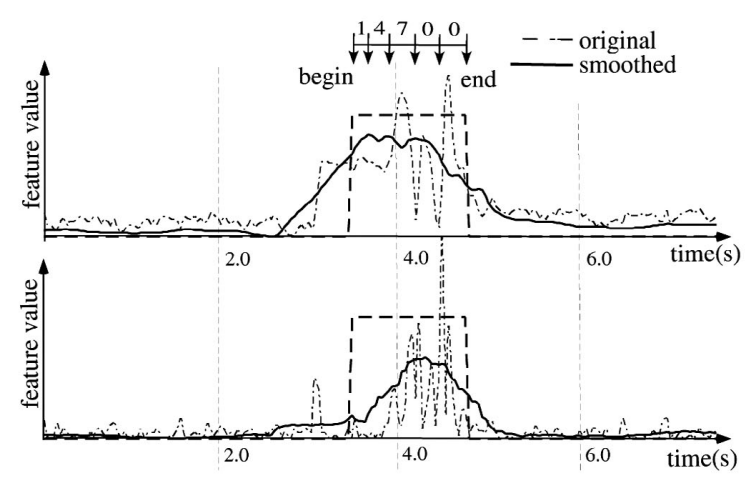

図 6 発話特徴例 (上：低輝度画素数, 下：低輝度画素数フレー 么間差分)

Examples of feature value for VAD.

(Top: Number of low-intensity pixels)

(Bottom: $\Delta$ Number of low-intensity pixels)

の判別関数 (音声閾值 $\Theta_{a}$, 画像閾值 $\Theta_{v}$ ) の論理積に基づく 統合法である。この方法の問題点は, 図 7 (a) に識別領域 を示すように口の動きが小さな発話時の未検出 (図 7(a) 中

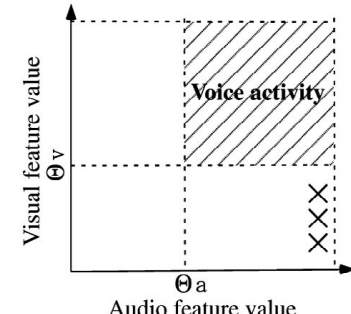

(a)Method 1: Logical AND

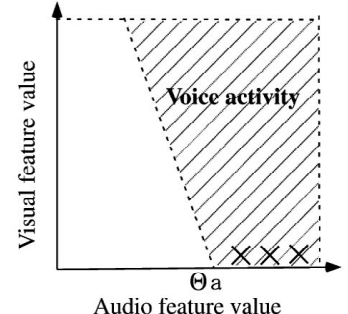

Audio feature value (b)Method 2: Threshold Shift
図 7 従来提案した判別関数例

Examples of previously proposed discriminant function. (a) Frequency

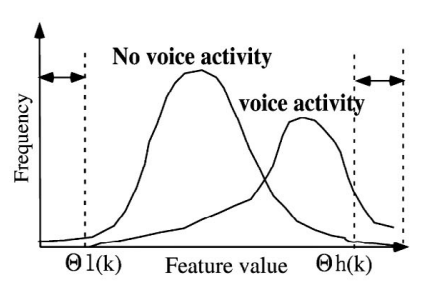

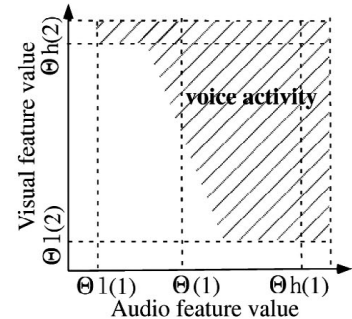

(b) Discrimination Space
図 8 提案する判別関数例

Examples of proposed discrimination function.
×）と，発話データごとの閾值を手動で設定している点で あった ${ }^{12)}$.

この問題解決のため，筆者らは画像特徵を用いて $t$ 番日 のフレームの音声特徵の閥值 $\Theta(1, t)$ を画像特徴で可変と する方法に変更し, 過去数フレームの特徵量の平均値, 分 散の基づく閾值の自動的設定法を示した(図 7(b)). この才 法の問題点は，音声特徵による判別を主体としたことによ る音声䛊検出 (図 7(b) 中 $\times$ ) と, 閾值制御のパラメー夕調 整の難しさであった ${ }^{14)}$.

本論文では，このう法をベースに上記問題を解決し，検 出精度を向上させた統合法を提案する。まず，提案方法 1 として前回提案した特徵ごとの識別性能差を考慮した未検 出対策を発展させ， $t$ 番目フレームの $k$ 番目の特徵である $F(k, t)$ の線形判別関数を $D_{k}(F(k, t), t)$ とし, その重み付 け和 $\Phi_{1}$ で構成される判別関数 $\Delta_{1}(t)$ を提案する. 判別関数 $\Delta_{1}(t)$ の閾值を $\Theta_{I}$, 特徵数を $l$, 特徵毎の閾値を $\Theta(k, t)$, 判別関数の重みを $W_{k}$ とすると統合法は式 $(7)$ で表される.

$$
\begin{aligned}
\Delta_{1}(t) & = \begin{cases}1 & \left(\Phi_{1}(t)>\Theta_{I}\right) \\
0 & (\text { 上記以外 })\end{cases} \\
\Phi_{1}(t) & =\sum_{k=1}^{l} W_{k} D_{k}(F(k, t), t) \\
D_{k}(F(k, t), t) & = \begin{cases}1 & (F(k, t)>\Theta(k, t)) \\
0 & (\text { 上記以外 })\end{cases}
\end{aligned}
$$

さらに，未倹出，誤倹出が少なくなるように識別領域を修 正する．発話データに対してそれぞれの特徴の発話と非発 話の分布は図 8(a)のような形状を持つ場合が多く，このよ うな場合には，分布の端の所では特徴単独でも発話と非発話 の判別が可能になる。 それぞれの特徵 $F(k, t)$ の上端付近の 閾值 $\Theta_{h}(k, t)$ による $t$ 番目のフレームの判別関数 $D_{h(k)}(t)$ の論理和を $D_{h}(t)$ とし, さらに下端付近の閾值 $\Theta_{l}(k, t)$ に よる判別関数 $D_{l(k)}(t)$ の論理積を $D_{l}(t)$ とすると, これら を元来の判別関数と組合せると, 図 8(b) のような新たな判 別関数が構成できる. 提案方法 2 として, 提案方法 1 の判 別関数 $\Delta_{1}(t)$ に上記の処理を施した判別関数 $\Delta_{2}(t)$ を提案 する (式 (8)).

$$
\begin{aligned}
\Delta_{2}(t) & =\left(\Delta_{1}(t) \vee D_{h}(t)\right) \wedge D_{l}(t) \\
D_{h}(t) & =D_{h(1)}(t) \vee D_{h(2)}(t) \vee \cdots \vee D_{h(l)}(t) \\
D_{l}(t) & =D_{l(1)}(t) \wedge D_{l(2)}(t) \wedge \cdots \wedge D_{l(l)}(t) \\
D_{h(k)}(t) & = \begin{cases}1 & \left(F(k, t)>\Theta_{h}(k, t)\right) \\
0 & (\text { 上記以外) }\end{cases} \\
D_{l(k)}(t) & = \begin{cases}0 & \left(F(k, t)<\Theta_{l}(k, t)\right) \\
1 & \text { (上記以外) }\end{cases}
\end{aligned}
$$

また, $\mathrm{t}$ 番目のフレームの $\mathrm{k}$ 番目の特徵に対する閾値 $\Theta(k, t)$ はこれまでの知見からノイズ状況に応じて調整す る必要があるが，そこに学習の朹組みを導入する。 $t$ 番目 のフレームに対して $2 \sim 4$ 秒前の非発話と判断された特徵 の平均値 $\bar{F}\left(k, t^{\prime}\right)$ 加閾值 $\Theta(k, t)$ を単回帰式 $\Theta(k, t)=$ $a(k) \times \bar{F}\left(k, t^{\prime}\right)+b(k)$ で推定する。平均值を取る区間長は 
充分に短く，かつノイズ変動の影響を受けにくさを考慮し， $0.6 s$ とした. 線形判別のための最適閾値は, 未検出と誤検 出のコスト比を定めれば，予め正解発話・非発話区間を与 えた学習デー夕に対する探索処理により最も低いコストを 持つ值として自動的に算出できる. その結果, $2 \sim 4$ 秒前の 非発話区間の特徽の平均值と最適閾值の分布に対する単回 帰式を学習デー夕から求めることができる. 提案方法 2 の 上端および下端付近の閾值 $\Theta_{h}(k, t), \Theta_{l}(k, t)$ も同様の方法 で設定する. 判別関数の重み $W_{k}$ と閾值 $\Theta_{I}$ は今回は固定 值とするが, 重み $W_{k}$ は学習用の発話データでランダムに パラメー夕探索して最適值を求める。

\section{3. ドライバの発話区間検出実験とその考察}

\section{1 評価用データ}

評価用デー夕は AURORA-3J-AV（現在構築中）を使用 した.これは, 音声認識の研究開発向けの公開型共通デー 夕ベースである AURORA データベースの中で, 車室内に おける日本語の音声タスク用の AURORA-3J をバイモー ダル用に拡張したものである ${ }^{18)}$.このデータベースは，実 道路走行中のドライバの発話した音声（連続数字/コマン ドタスク）とドライバの顔画像を収録したもので，図 1 の 音声デー夕例のように, デー夕長は $6 \sim 10$ 秒で 1 回の連続 数字発話を含む形式である. 音声デー夕は, サンバイザ付 近に取り付けたハンズフリーマイクで収集した。 雑音要素 はオーディオシステムからの楽曲音, エアコンの吹き出し 音, 空開けによる風切り音で, 車室内の典型的な大きな雑 音 3 種類を選択した. 画像デー夕は近赤外カメラ (SONY 製 XC-E150) で撮像した。 カメラはステアリングコラム付 近に取り付け (図 3), $870 \mathrm{~nm}$ の可視光カットフィルタを装 着し, 近赤外 LED で照明している. 実画像例は前節の図 4 に示す。杂隹音要素は外乱光による照明変動（太陽直射を 含む), 頭部の姿勢と動きで, 通常運転時の雑音と考えら れる。音声は $48 \mathrm{kHz}$ サンプルデータを $16 \mathrm{kHz}$ にダウンサ ンプリングしたデータフォーマットを用いた。画像の解像 度は $352 \times 240$ 画素であり, フレーム周期 $29.97 \mathrm{~Hz}$ の DV フォーマットでエンコードされた $720 \times 480$ 画素のインタ レース画像からトップフィールドのみを使い水平方向をダ ウンサンプリングして作成した。評価はデータベースから 選択した 80 発話を用いた。発話者は $20 \sim 50$ 才台, 男性 45 名, 女性 35 名, 音声ノイズはオーディオ 29 例とエアコン 26 例と空開け 25 例である。

\section{2 各特徵量単独の発話区間検出性能評価}

第 2 節で示した音声と画像の各発話特徵量単独の発話区 間検出性能を評価する.未検出と誤検出のコスト比は $4: 1$ とした，発話デー夕を 3 分割し， $1 / 3$ を評価に， $2 / 3$ を回 帰式による閥值推定のパラメー夕学習に用いた。 その操作 を 3 回行うことですべてのデータでの評価を行った。 なお， 評価と学習には同一の人物の発話は含まれていない.

評価は同時に収録した接話マイクの出力波形から手作業
で求めた正解発話区間 (Ground Truth) に対して, 特徵值 による検出区間を比較することで実施した.すすへてての評価 データに扔ける正解発話区間フレーム数 $P_{v a d}$ に対する検 出フレーム数 $P_{h t}$ と未検出フレーム数 $P_{m s}$, 扔よび正解非 発話区間フレーム数 $\left(P_{n}\right)$ に対する誤検出フレーム数 $\left(P_{f a}\right)$ と非検出フレーム数 $\left(P_{c r}\right)$ を求め, 検出率 $R_{h t}$ (式 $\left.(9)\right)$ と 誤検出率 $R_{f a}$ (式 (10)) から $\mathrm{ROC}$ 曲線で比較した.

$$
\begin{aligned}
R_{h t}[\%] & =\frac{P_{h t}}{P_{v a d}} \times 100 \\
R_{f a}[\%] & =\frac{P_{f a}}{P_{n}} \times 100
\end{aligned}
$$

図 9 に音声と画像の発話特徵量毎の ROC 曲線を示す. 図中のシンボルは各特徵の検出の閾値を調整して得られた すべての評価デー夕に対する評価結果実例である．各曲線 が左上になるほど性能が良いことを示す．検出性能として 全体的に画像が音声より高くなった。これは音声は大きな 雑音状況を選択的に収集したのに対し，画像は通常の雑音 状況のためと考えられる。

画像発話特徴では, 従来のフレーム間輝度差分 (Sum of Squared Difference)に比べて, 筆者らの提案したものはす ベて有意な性能差を示し, 特にフレーム間正規化差分 (Normalized Difference) は高い判別性能を示した. 今回の検討 では, 口唇画像の検出誤りは生じなかった。そのため画像 発話特徵の問題は, 発話区間以外での口の動きと発話時の 単語や個人差による口の小さな動きである．また低輝度画 素数 (Low Intensity Pixels) はさらに以下の問題が生じた. 一つは閾值設定に関するもので, 今回は口袁画像初期フレー ムの輝度ヒストグラム累積值が $3 \%$ になるところで低輝度間 値を設定したが，最初に口を開いている場合などで不適に なる場合があったもう一つは一部のデータで顔への LED 照明による影が生じ，顔の動きによる照明変動に若干影響 を受けた点である。

音声発話特徴では，ゼロ交差数 (Zero-Cross) はノイズが エアコン吹き出し, 空開けの場合と比べて楽曲音（ボーカ ル曲）の場合に検出性能が劣化した。これはゼ口交差数が 発話音の特性を示す特徵であり, 発話とボーカル曲が共に 発話音の特徵を有したためと考えられる. 雑音除去した対 数パワー (Log Power NR) はノイズの種類による劣化の差 が小さかった. またノイズ除去を行わない対数パワー (Log Power) は予想通り, 劣化が影著であった.

\section{3 特徵量統合による発話区間検出性能評価 1}

第 2 節で提案した音声および画像の発話特徵を統合した $\mathrm{VAD}$ 法の有效性を確認するため, 従来法拈よび単独の特徴 による判別法との比較評価を実施した。評価用のデー夕は 前節と同じ 80 発話である. 従来法として決定段階統合法 で単独な特徴の判別関数の論理積に基づく手法（筆者らの 従来提案した手法）と論理和に基づく手法，さらに特徴段 


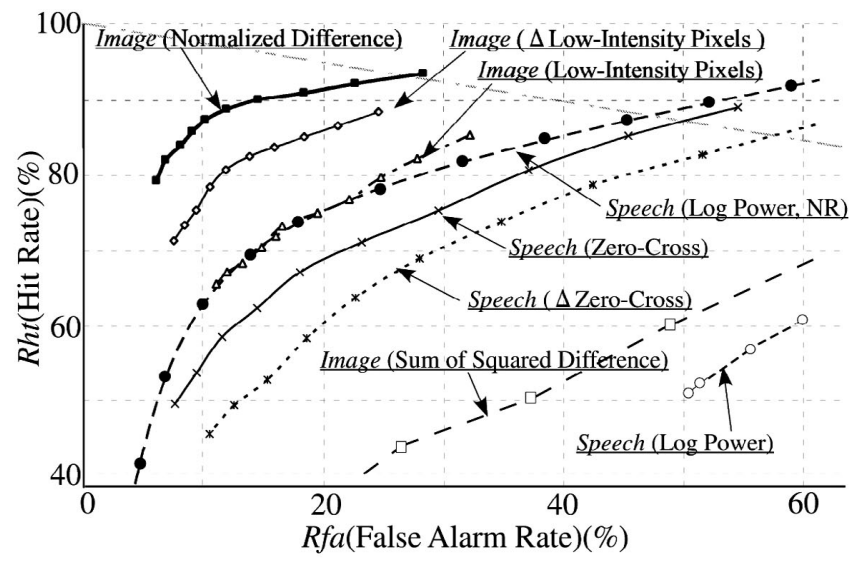

図 9 音声・画像特徵単独の VAD の ROC 曲線 ROC Curve for speech- or image-based VAD.

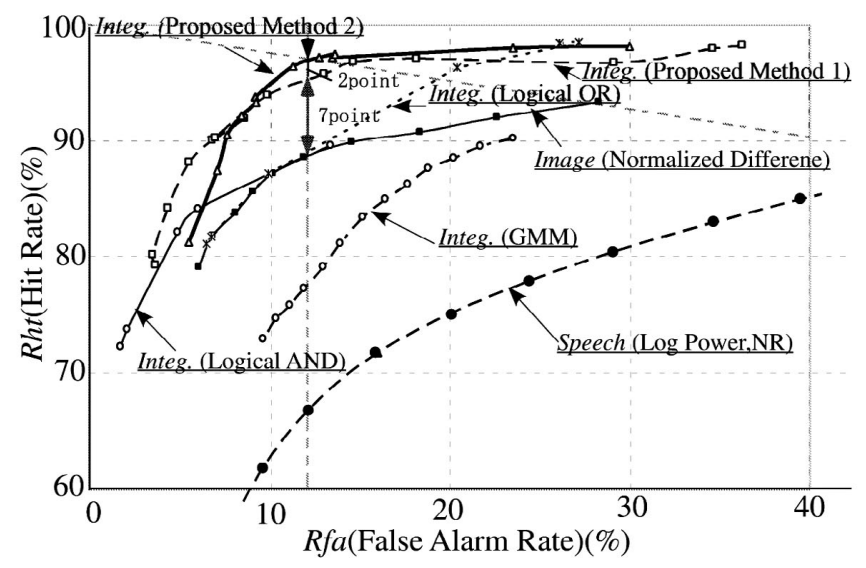

図 10 統合による VAD の ROC 曲線 ROC Curve for VAD based on feature integration.

階統合として $\mathrm{GMM}^{* 19)} に よ る$ 発話区問検出法を用いた。 特徵段階統合は音声と画像それぞれ 3 種，合計 6 特徵を 入力として発話・非発話を判別する方法となり, 識別器と しては $\mathrm{SVM}^{* 20)}, \mathrm{GMM}$ を事前評価し, 性能差が少ないの で単純な GMM を選んだ. GMM は混合分布数 16 で, 発 話, 非発話の二つの GMM を学習により求めた。学習は提 案方法 1,2 と同様に, 発話デー夕を 3 分割し, $1 / 3$ を評価 に，2/3を学習に用いた.

図 10 に ROC 曲線を示す. 図中のシンボルは各判別法 の閾值を調整して得られたすべての評他デー夕に対する評 価点である. 提案方法 1 と 2 は誤検出率 $12 \%$ の点で検出率 $97 \%$ 達成し, 従来方法に比べてそれぞれ約 7 ポイントお よび約 9 ポイントの検出率向上が確認できた．未検出と誤 検出のコスト比を $4: 1$ と設定した (図 10の一点鎖線). 誤 検出率 $12 \%$, 検出率 $97 \%$ (未検出率 $3 \%$ ) の点はその条件を 満たす点であり，比較の基準として誤検出率 $12 \%$ を選択し た(図 10 の 2 点鎖線). な打提案方法 2 が誤検出率が $8 \%$ よ り低くなると提案方法 1 より性能劣化しているが, 未検出 と䛊検出のコスト比が $4: 1$ のところで判別関数の間值を 最適化しているためである.

\footnotetext{
* Gaussian Mixture Model

* Support Vector Machine
}

表 1 VAD の評価結果

Evaluation Result of VAD

\begin{tabular}{l||c|c|c}
\hline \hline & $\begin{array}{c}\text { 音声 } \\
\text { Speech }\end{array}$ & $\begin{array}{c}\text { 画像 } \\
\text { Image }\end{array}$ & $\begin{array}{c}\text { 音声と画像の統合 } \\
\text { Bimodal }\end{array}$ \\
\hline $\begin{array}{l}\text { 検出率 (\%) } \\
\text { Hit Rate }\end{array}$ & 90.5 & 93.6 & 97.5 \\
\hline $\begin{array}{l}\text { 誤検出率 (\%) } \\
\text { False Alarm Rate }\end{array}$ & 34.9 & 20.6 & 11.8 \\
\hline $\begin{array}{l}\text { 木検出回数 } \\
\text { Miss Detection Number }\end{array}$ & 24 & 13 & 9 \\
\hline $\begin{array}{l}\text { 誤検出回数 } \\
\text { False Alarm Number }\end{array}$ & 81 & 72 & 61 \\
\hline
\end{tabular}

従来法の論理和，論理積に基づく手法は特徵単独で最も 検出性能の高い正規化差分值に基づく検出法に漸近した. 特徵段階統合法の一例である GMM による判別法は誤検出 率 $12 \%$ の点で検出率 $76 \%$ となり, 画像単独の判別関数より も検出性能が低かった。提案方法では発話の $2 \sim 4$ 数秒前の 非発話区間の特徵量の半均値を発話判定に利用しているが, その効果が大きいと予想できる，GMMでも特徵を単純に そのまま並べて学習させるのではなく, 雑音や発話レべル の違いに対して正規化などの前処理が必要と思われる。

\section{4 特徵量統合による発話区間検出性能評価 2}

第 3.3 節で高い区間検出性能が確認された提案方法 2 を 用い，音声，画像単独に対するバイモーダルの統合法の効 果を比較評価する，性能向上のため，発話，非発話区間と も区間長が $100 \mathrm{~ms}$ 以下の場合はノイズとして除去する処理 を加えた。

表 1 に 80 発話での検出率, 誤検出率, 未検出回数, 誤 検出回数を示す.未検出と誤検出のコスト比は $4: 1$ に設定 した。 未検出，誤検出回数は未検出および誤検出の発生回 数で両者とも一発話に対して複数回起こりうる. 音声で 24 回の未検出をバイモーダルで 9 回に削減でき，バイモーダ ルのVAD の実用的な効果が確認できた.

\section{4. むす び}

実走行車内環境に扔ける音声認識性能の向上を目指した バイモーダルの発話区間検出手法について，画像の発話特 徵およびその統合法を提案し，公開用データベースである AURORA-3J-AV で評価し，その有効性を明らかにした。

画像発話特徵として, 口の動きに対応した正規化差分と 開度に対応した低輝度画素数を提案し，単独では正規化差 分が高い検出性能を示し，低輝度画素数も統合の特徵とし て相補的に利用できることがわかった。

また, 統合法については従来の音声と两像それぞれの判 別関数の論理積または論理和法に対して, 判別関数の重み付 け和手法およびさらに単独特徵の判別関数の論理積・論理和 を組合せる方法を提案した．評価の結果，誤検出率 $12 \%$ の 点で検出率 $97 \%$ を達成し，従来方法に比べてそれぞれ約 7 ポイントおよび約 9 ポイントの検出率向上が確認できた. 音声，画像，バイモーダルのそれぞれの発話区間検出率は， 未検出と誤検出のコスト比は $4: 1$ に設定した時に, $90.5 \%$, 
$93.6 \%, 97.5 \%$ となり, バイモーダルの統合の効果も確認 できた。

発話区間検出は, 最終的には狭義の音声認識と組合せた 音声認識性能で評価すべきであるが，そのために先ず必要 となる区間レベルでの性能把握を実施した。また，画像デー 夕を扱い，1フレーム単位での人手による評価などの都合 上, 評価デー夕数が充分とは言えないが, 可能性を示す評 価結果として報告した．音声認識性能評価とデー夕数の拡 充も今後の課題としたい.ささらに, 評価デー夕数の拡充に おいては悪環境の画像や CENSREC-1-C ${ }^{21)}$ のような複数 の発話が含まれるデータでの評価も必要である。

研究を進めるにあたり，熱心に議論頂いた名古屋大学大 学院情報科学研究科メディア科学専攻末永研究室, 武田研 究室の皆様, AURORA-3J-AV の収集に貢献された皆様に 深く感謝する。なお本研究の一部は, 文部科学省科学研究 費補助金, 21 世紀 COE プログラム「社会情報基盤のため の音声映像の知的統合」の援助を受けて行われた.

\section{〔文献〕}

1) R. L. Bouquin-Jeannesw, G. Faucon : "Study Of A Voice Activity Detection And Its Influence On A Noise Reduction System," Speech Comm.,16, pp.245-254(1995)

2) J. Sohn, N. S. Kim, W. Sung : "A Statistical Model-based Voice Activity Detection," IEEE Signal Processing Lett., 6, 1, pp.13(1999)

3）近藤啓介, 長井隆行, 金子正秀, 榑松 明：“マイクロフォンアレー を用いた話者位置推定による車載音声認識,”信学論 (D- II ), J85，7， pp.1176-1187(2002)

4) N. Shiraki, M. Andoh, Y. Ninomiya, S. Tokoro: "A Rapid Facialdirection Detection System Based On Symmetrical Measurement, " Proc of 12th ITS World Congress, 3817, (2005),

5）奥村 晃弘, 濱口 佳彦, 岡野 健治, 宮崎 俊彦: “顔画像情報と音声情報 の統合による発話認識,”情処学論, $, 39,12$, pp.3232-3241(1998)

6) X.Zhang, R.M.Mcrscrcau, M.Clements, C.C.Broun : "Visual Speech Feature Extraction For Improved Speech Recognition," IEEE ICASSP 2002, II, pp.1993-1996(2002)

7) D.Sodoyer, B. Rivet, L. Girin, J-L. Schwartz, C. Jutten : "An Analysis Of Visual Speech Information Applied To Voice Activity Detection," IEEE ICASSP 2006, I, pp.601-604(2006)

8）田村哲嘼, 岩野 公司, 古井 貞熙：“オプティカルフローを用いたマ ルチモーダル音声認識法の提案と評価,”情処学研資, 2002-SLP-40-6, 2002, 10, pp.33-38(2002).

9）間瀬 健二, Alex Pentland：“オプティカルフローを用いた読唇,”テレ ビ学技報, 13,44, pp7-12(1989)

10）村井和昌, 野間 啓介, 熊谷 健一, 松井 知子, 中村 哲 : “口周团画像 による頑強な発話検出,”音声言語情報処理, No.34-13(2000)

11）村井 和昌, 中村 哲：“画像と音声情報の併用による雑音に頑強な発話 検出,”情処研報, 2001-SLP-37-10, pp.55-60(2001)

12）坂 義秀, 前野 俊希, 二宮 芳樹, 森 健策, 末永康仁: “車載カメラ 映像を用いたドライバの発話区間検出,”信学技報, PRMU2002-261, pp.111-116(2003)

13）松田 博義, 増田 健, 淁口 哲也, 有木 康雄, 神谷 昌宏 : “AdaBoost と音声・唇 GMM による発話区間検出,”平 18 信学総全大, D-14-7, pp.131(2006)

14）前野 俊希, 根木 大輔, 北坂 孝幸, 森 健策, 末永 康仁, 二宮 芳樹 : “本載カメラ映像を用いたドライバの発話区間検出の改善,”信学技報, PRMU2003-257, pp.7-12(2004)

15) T. H. Dat, K. Takeda, F. Itakura : "Maximum A Posterior Probability And Cumulative Distribution Function Equalization Methods For Speech Spectral Estimation With Application In Noise Suppression Filtering, " Lecture Notes in Computer Science, 3817, pp.328-337(2006)

16）前野 俊希, 北坂 孝幸, 森 健策, 末永 康仁, 二宮 芳樹： “非線形フィル タとテンプレートマッチングによるドライバの顔部品抽出,”平成 15 年 度電気関係学会東海支部連合大会講演論文集, pp.324(2003)

17) F. Cremer, K. Schutte, J.G.M. Schavemaker, E. den Breejen : "A Comparison Of Decision-level Sensor-fusion Methods for
Personnel Landmine Detection, " Information Fusion 2, pp.187208(2001)

18）根木 大輔, 前野 俊希, 北坂 孝幸, 森 健策, 末永 康仁, 宮島 千代美, 伊 藤 克亘, 武田一哉, 板倉 文忠, 佐野 昌己, 二宮 芳樹 : “バイモーダル 車内音声認識柿価用データベースの構築,”情処研報, 2005-SLP-55-07, pp.35-40(2005)

19）藤本雅清, 有木康雄：“GMM と EM アルゴリズムを用いた加法性雑音㧍 よび乗法性歪みの抑圧,”信会論 (D- II ), J88, 7, pp.1093-1102(2005)

20) V.N.Vapnik : "Statistical Learning Theory," John Wiley \& Sons, (1998)

21）IPSJ-SIG SLP 雑音下音声認識評価ワーキンググループ： http://sp.shinshu-u.ac.jp/CENSREC/index.html.ja

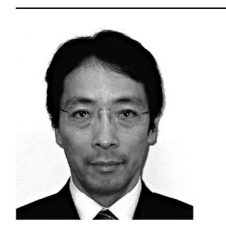

にの怒皆樹 1981 年名古屋大学工学部電子工学科 卒, 1983 年同大大学院工学研究科修士課程修了. 同年, (株) 豊田中央研究所に入社. 2006 年より同研究所主席 研究員. 主として画像処理の自動車応用に関する研究に 従事. 止会員.

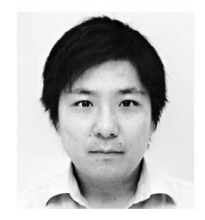

坂望義秀 2001 年名古屋大学工学部電気電子. 情 報卒, 2003 年同大大学院情報科学研究科修士課程修了. 同年, (株) 口本 IBM に入社. 大学在学中はマルチメディ ア信号処理の研究に従事. (本研究は在学中のもの)

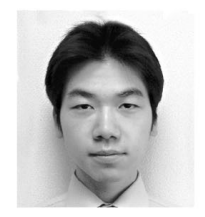

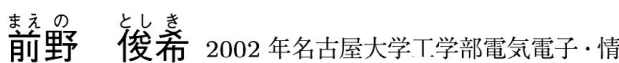
報卒, 2004 年.同大大学院情報科学研究科修士課程修了. 同年, (株) 日立製作所に入社. 大学在学中はパターン認 識の研究に従事. (本研究は在学中のもの)

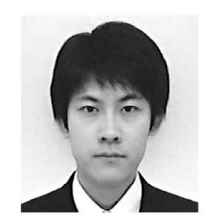

根萻 犬輔 2003 年名古屋大学工学部電気電子・情 報卒, 2005 年同大大学院情報科学研究科修士課程修了. 同年, ソニー (株) に入社. 大学在学中はマルチメディア 信号処理の研究に従事. (本研究は在学山のもの)

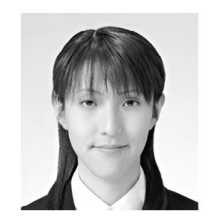

歊島声占美 2001 年名古屋工業大学大学院工学研 究科電気情報工学専攻博士後期課程修了. 同年, 同大知 能情報システム学科助手. 2003 年より名古屋大学大学 院情報科学研究科メディア科学専攻助手. 現在, 同尃攻 助教. 行動信号処理, 音声情報処理に関する研究に従事. 博士 (工学).

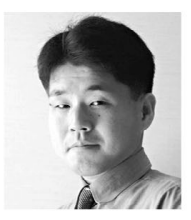

㧲健策 1996 年名古屋大学大学院工学研究科 博士後期課程修了. 同年, 同大日本学術振興会特別研究 員. 2000 年名古屋大学助教授. 2001 年スタンフォード 大学客員助教授. 2003 年名古屋大学情報科学研究科助教 授. 現在, 同准教授. 三次元画像処理, 医学応用, C G に関する研究に従事. 博十. (工学).

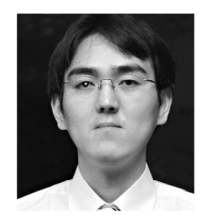

菲弶等出 2002 年名古屋大学大学院工学研究科 博士後期課程修了. 2003 年, 同大大学院情報科学研究科 助手. 現在, 同専攻助教. 三次元画像処理, 人体パター ン認識, 医学応用に関する研究に従事. 博士 (工学).

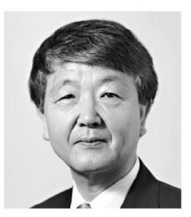

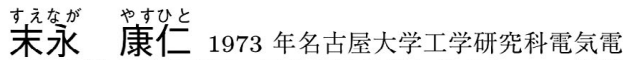
子専攻博士過程修了. 同年電電公社に入社し， 24 年間 NTT 研究所にて画像処理の研究に従事. 1997 年名古屋 大学教授. 現在, 同大学情報科学研究科教授. 画像認識, 画像生成, 医用画像処理の研究に従事. 博士 (工学). 